\title{
Viróides em citros no Estado do Rio de Janeiro
}

\author{
Jocarstea Aparecida Brinati Leone ${ }^{1, *} \oplus$, Jorge Ferreira de Souza ${ }^{2} \oplus$, André Felipe Andrade dos Santos ${ }^{3} \oplus$, \\ Paulo Sergio Torres Brioso ${ }^{1}$
}

${ }^{1}$ Laboratório Oficial de Diagnóstico Fitossanitário/ UFRRJ, BR 465, Km 05, 23897,970, Seropédica, RJ, Brasil. ${ }^{2}$ EMATER-RIO, Rua Bernardo Vasconcelos, 791, Centro, 28970-000, Araruama, RJ, Brasil. ${ }^{3}$ Departamento de Genética, IB/ CCS/ UFRJ, Avenida Carlos Chagas Filho, 373, Cidade Universitária, 21944-970, Rio de Janeiro, RJ, Brasil. *Bolsista Capes

Autora para correspondência: Jocarstea Aparecida Brinati Leone (jobrinati@yahoo.com.br)

Data de chegada: 12/11/2019. Aceito para publicação em: 15/03/2020.

$10.1590 / 0100-5405 / 231001$

\section{RESUMO}

Leone, J.A.B.; Souza, J.F.; Santos, A.F.A.; Brioso, P.S.T. Viróides em citros no Estado do Rio de Janeiro. Summa Phytopathologica, v.46, n.2, p.121-128, 2020.

Os viróides infectam plantas de grande importância econômica como os citros. Objetivando detectar a presença de viróides através de métodos moleculares em árvores cítricas, cinco propriedades em Araruama, no Estado do Rio de Janeiro foram avaliadas. Vinte e duas amostras foram coletadas a partir de plantas com nanismo, rachadura no tronco e epinastia, sendo realizada a extração de RNA das folhas e empregado a técnica de RT-PCR com primers específicos para cinco espécies de viróide que infectam citros. O resultado da eletroforese em gel de agarose mostrou-se positivo para os viróides Citrus exocortis viroid (CEVd); Citrus bent leaf viroid (CBLVd); Hop stunt viroid (HSVd) e Citrus dwarfing viroid (CDVd), sendo o último encontrado em todas as propriedades e na combinação com outros viróides, o HSVd e o CBLVd estavam presentes em duas propriedades e o CEVd isoladamente em apenas uma propriedade. Não foi detectada a presença do Citrus viroid IV (CVdIV) nas amostras avaliadas. Foram observadas diferenças na expressão dos sintomas associados ao CEVd o que pode ter ocorrido devido a interferências entre as espécies de viróides que infectavam uma mesma planta. A transmissão pode ter sido mecanicamente através da poda das plantas cítricas ou através de mudas infectadas com viróide. A utilização de métodos moleculares mostrou-se eficiente na identificação da presença de viróides em plantas cítricas no Estado do Rio de Janeiro.

Palavras-chave: Citrus limonia, Fitopatógeno. Detecção. Teste de Reverse Transcriptase-PCR

\section{ABSTRACT}

Leone, J.A.B.; Souza, J.F.; Santos, A.F.A.; Brioso, P.S.T. Viroids in citrus in the state of Rio de Janeiro. Summa Phytopathologica, v.46, n.2, p.121-128, 2020 .

Viroids infect plants of great economic importance such as citrus. With the aim of detecting the presence of viroids by molecular methods in citrus trees, five farms in Araruama, Rio de Janeiro State, were evaluated. Twenty-two samples were collected from plants showing dwarfism, trunk cracking and hyponastic response; RNA was extracted from their leaves and the RT-PCR technique was used with specific primers for five viroid species that infect citrus. The result of agarose gel electrophoresis was positive for Citrus exocortis viroid (CEVd), Citrus bent leaf viroid (CBLVd), Hop stunt viroid (HSVd) and Citrus dwarfing viroid (CDVd); the latter was found in all farms and in combination with other viroids. HSVd and CBLVd were present in two farms and CEVd alone in only one farm. Citrus viroid IV (CVd-IV) was not detected in the evaluated samples. Differences in the expression of CEVd-associated symptoms were observed, which may have occurred due to interference of viroid species infecting the same plant. Transmission may have been mechanical through pruning of citrus plants or through viroid-infected seedlings. The use of molecular methods was efficient in identifying the presence of viroids in citrus plants in the state of Rio de Janeiro.

Keywords: Citrus limonia, Phytopathogens. Detection. Reverse Transcriptase-PCR Test.

Os citros são considerados originários das regiões subtropicais e tropicais do sul e sudeste da Ásia. As plantas cítricas pertencem ao gênero Citrus da família Rutaceae, no qual, estão incluídos as laranjas (Citrus sinensis (L.) Osbeck), tangerinas (Citrus reticulata Blanco e Citrus deliciosa Tenore), limões [Citrus limon (L.) Osbeck], limas ácidas Tahiti (Citrus latifolia Tanaka) e galego [Citrus aurantiifolia(Christm.) Swingle], lima da Pérsia (Citrus limettioides Tanaka), pomelo (Citrus paradisi Macf.), cidra (Citrus medica L.), laranja azeda (Citrus aurantium) e toranjas [Citrus grandis (L.) Osbeck] (15).

A citricultura tem um grande destaque no Brasil. O país detém também a maior produção mundial de frutas cítricas, com uma área plantada estimada em 670.564 hectares e produtividade de 22.064 kg.ha- ${ }^{-1}(14)$. Além do país ser considerado o maior produtor mundial de suco de laranja, exporta cerca de $98 \%$ da sua produção de laranja (16) e obteve aumento na demanda internacional de $28 \%$ quando comparado ao período de 2016/ 2018 (14). A produção média em 2018 foi de aproximadamente 17.100.491 toneladas (10), sendo os principais estados produtores Minas Gerais, Paraná, Rio Grande do Sul e São Paulo (11).

O Estado de São Paulo e a região do Triângulo/ Sudoeste Mineiro são os maiores produtores, em uma área de plantio de aproximadamente 465.635 hectares de citros. A estimativa de safra para estas regiões em 2018/ 2019 foi de 288,29 milhões de caixas (13). 
No Estado do Rio de Janeiro a área total de plantação de laranja, limão, tangerina e tangerina poncã é cerca de 7.426,77 hectares, sendo os municípios de Araruama e de Rio Bonito, as regiões com maior produção (19). Em 2017, a produção de frutas cítricas no Estado do Rio de Janeiro foi de 115.825,46 toneladas aproximadamente (20).

A citricultura brasileira tem uma grande importância no desenvolvimento socioeconômico do país, cerca de 230 mil empregos são gerados na área rural (16), além da arrecadação de impostos para o Brasil, contribuindo assim para o aumento do PIB brasileiro.

Entre os fatores que mantém a citricultura competitiva no país estão o desenvolvimento de tecnologias, como densidade de plantas por hectare, mudas de melhor qualidade, variedades mais bem adaptadas e melhores combinações de porta-enxertos. Os portaenxertos influenciam em diversas características das plantas como os níveis de sólidos solúveis totais, tamanho da copa e do fruto, resistências a agentes causadores de doenças e ao frio, dentre outras (18).

Entre os agentes que causam danos a citricultura estão os viróides. Eles são os menores fitopatogénos conhecidos, com genoma de RNA de fita simples, circular, com forte estrutura secundária, compreendendo entre 246 a 401 nucleotídeos, sem capa proteica e dependendo da célula hospedeira para a sua replicação. Os viróides estão classificados em duas famílias, oito gêneros 32 espécies e diversas variantes de sequência de acordo com as características biológicas e moleculares (9).

Os viróides podem causar sintomas em plantas cítricas como malformações nas folhas, epinastia, rugosidade, lesões cloróticas e necróticas, rachaduras no caule, exsudação de goma, induz nanismo na planta, definhamento da copa, amarelecimento, e em casos mais extremos pode levar a morte da planta. Em alguns eventos acontece a ausência de sintomas. Os viróides não possuem vetores e dificilmente são transmitidos por pólen e sementes, mas podem ser transmitidos mecanicamente com muita facilidade e por instrumentos de poda contaminados. O intercambio de material propagativo é a principal via de disseminação (2).

Os viróides Chrysanthemum stunt viroid (CSVd), Citrus exocortis viroid (CEVd) e Coleus blumei viroid (CBVd) foram identificados e caracterizados no Brasil, infectando de forma natural plantas como crisântemo, citros e Coleus, respectivamente. Hop stunt viroid (HSVd) e Potato spindle tuber viroid (PSTVd) foram interceptados em materiais de amostras vegetais sujeitos a quarentena (5). O mesmo autor destacou a ocorrência de CEVd, Citrus viroid II (CVd-II $=H o p$ stunt viroid $)$ e Citrus viroid III (CVd-III = Citrus dwarfing viroid $)$ associados ao "Exocorte" em citros em São Paulo e, CEVd e HSVd em videiras no Rio Grande do $\operatorname{Sul}(5,6)$.

Os citros naturalmente podem ser hospedeiros de, pelo menos, sete espécies de viróides dentre eles: Citrus exocortis viroid (CEVd), Citrus bent leaf viroid (CBLVd), Hop stunt viroid (HSVd), Citrus bark cracking (CBCVd), Citrus dwarfing viroid (CDVd), Citrus viroid $\mathrm{V}$ (CVd-V) e Citrus viroid VI (CVd-VI). Estes viróides ocorrem em infecções simples ou mistas e, com isso, pode existir interferências e sinergismos entres eles $(3,4,8,12$,).

No Estado do Rio de Janeiro, até o momento não existem pesquisas ou levantamentos de viróides em citros. Desta forma, objetivou-se realizar um levantamento e identificar molecularmente os viróides em citros no município de Araruama, no Estado do Rio de Janeiro e propor estratégias de controle.

\section{MATERIAL E MÉTODOS}

\section{Local do experimento e coleta das amostras}

As coletas de material vegetal, utilizado como fonte de viróides, foram realizadas no município de Araruama, Região dos Lagos, litoral do Estado do Rio de Janeiro (22 $52^{\circ}$ ' $22^{\prime \prime}$ S de latitude e $42^{\circ} 20^{\prime} 35^{\prime}$ " de longitude). Foram coletadas 22 amostras de plantas Limão 'Cravo' enxertadas no porta-enxerto Limão 'Cravo' ou no 'Citromelo', de cinco propriedades distintas (Tabela 1).

Folhas de citros oriunda de plantas com sintomas de rachaduras no tronco, nanismo, clorose e epinastia (Figura 1) e de plantas assintomáticas foram coletadas de forma aleatória nos pomares, identificadas, armazenadas em sacos plásticos e levadas para o Laboratório Oficial de Diagnóstico Fitossanitário (L.O.D.F) na Universidade Federal Rural do Rio de Janeiro UFRRJ. As amostras foram mantidas a temperatura média de $6 \pm 1^{\circ} \mathrm{C}$ por $24 \mathrm{~h}$ até o início das análises.

As amostras passaram por um processo de assepsia, ou seja, as folhas coletadas foram colocadas em caixas Gerbox e adicionado água (destilada e autoclavada), permanecendo por 15 minutos na mesma, em seguida as folhas foram deixadas em $\mathrm{NaClO} 0,25 \%$ durante 15 minutos e novamente em água (destilada e autoclavada) por 15 minutos. As folhas foram deixadas em papel filtro para a retirada do excesso de água e, em seguida, conduzidas para a extração de RNA.

\section{Inoculação Mecânica}

Dez plantas sadias de Gynura sp., pertencente à família Asteraceae, foram inoculadas mecanicamente com extrato de folhas de citros com sintomas de epinastia e clorose da propriedade 1 sendo mantidas em casa

Tabela 1. Informações sobre as amostras coletadas no Município de Araruama/ RJ

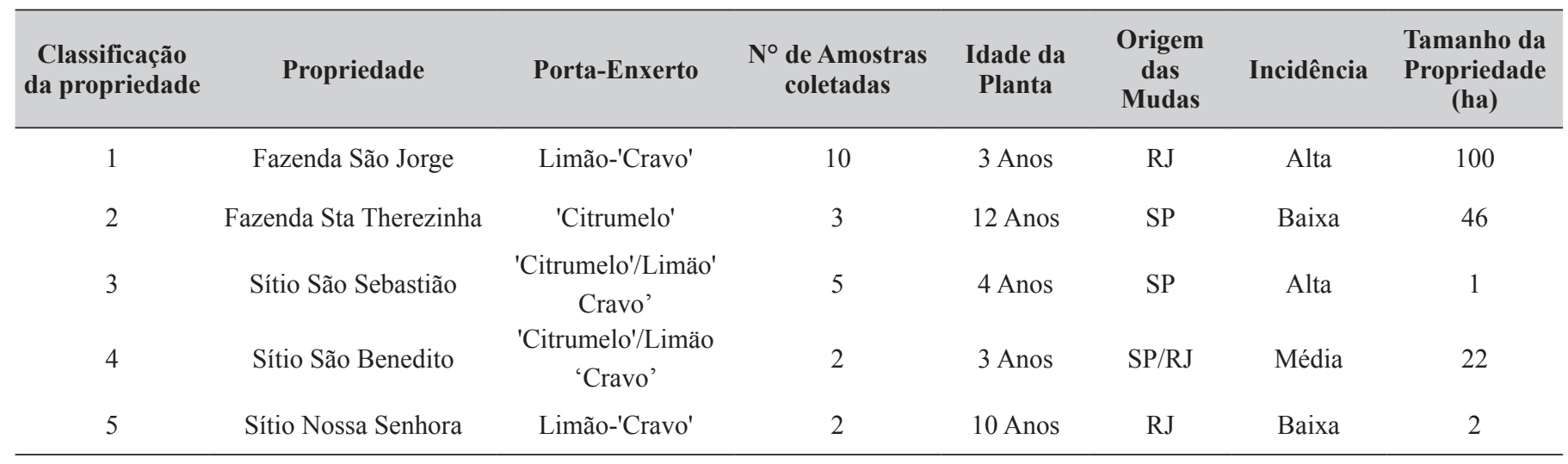




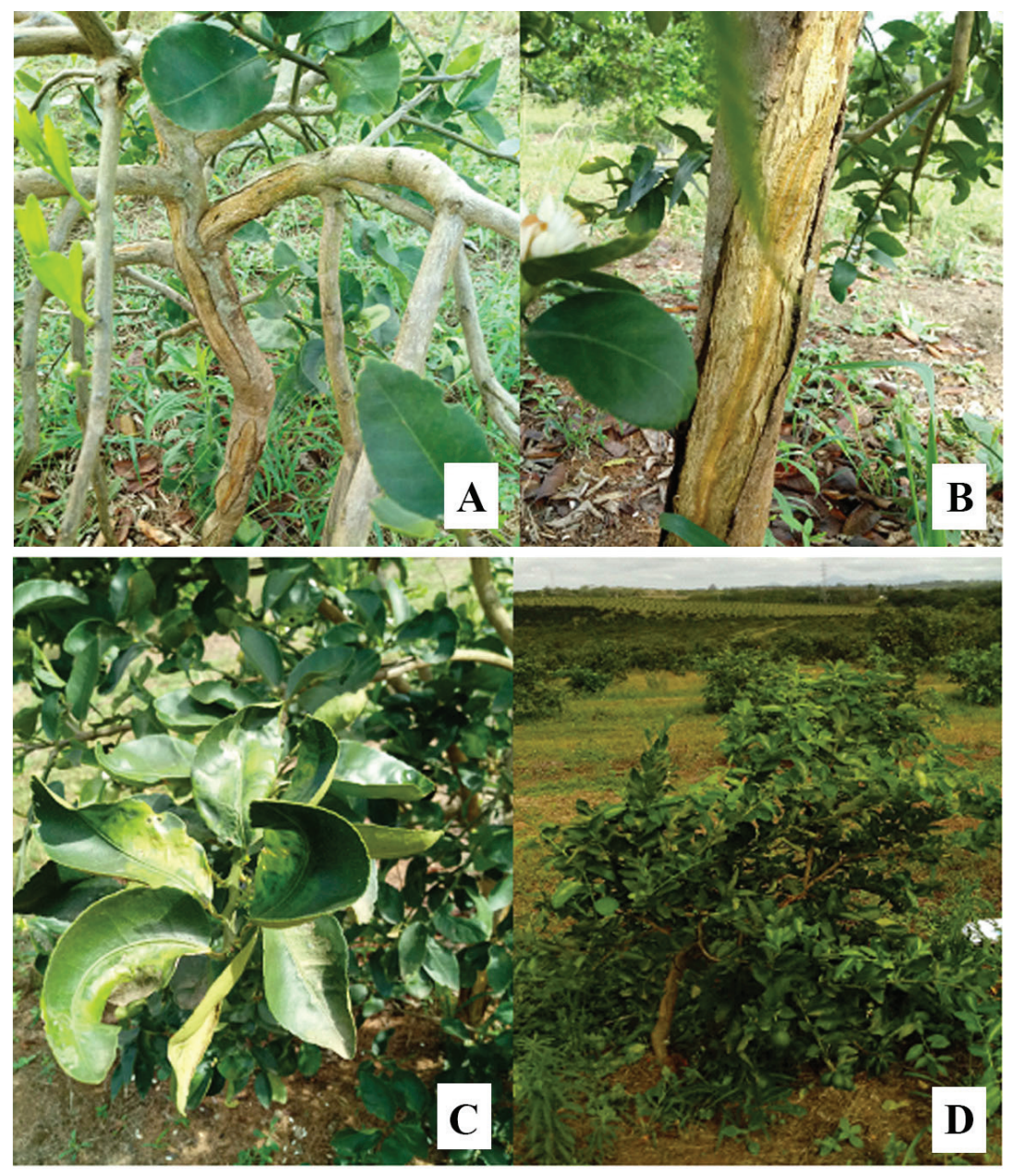

Figura 1. Plantas cítricas enxertadas em Limão 'Cravo'. As plantas pertencem a propriedade 1 (Fazenda São Jorge) no município de Araruama (RJ). As amostras apresentaram sintomas típicos de viróide. Na figura A e B, foi observado rachaduras acentuadas no tronco. Na figura C as folhas apresentaram descoloração e epinastia. Na figura D é possível observar que a planta não se desenvolveu, apresentando nanismo, sendo este sintoma característico da doença.

de vegetação. O inóculo foi preparado com $0,1 \mathrm{~g}$ das folhas de citros maceradas em almofariz e pistilo, previamente limpos e autoclavados, contendo $0,1 \mathrm{~g}$ de celite e $9 \mathrm{ml}$ de tampão de fosfato de sódio $0,01 \mathrm{M}$ $\mathrm{pH}$ 7.0. Dez plantas foram utilizadas como controle e friccionadas apenas com tampão fosfato de sódio. Durante 30 dias as plantas foram observadas quanto a presença de sintomas.

\section{Extração de RNA}

A extração de RNA das amostras coletadas foi realizada de acordo com o protocolo do RNeasy Plant Mini kit (QIAGEN Brasil). Utilizouse para o procedimento $0,1 \mathrm{~g}$ de parte do tecido, como nervuras e limbo de folhas jovens de citros e, triturados em almofariz com auxílio de pistilo (previamente tratados com solução de DEPC e autoclavados), em presença de nitrogênio líquido. Após, foi acrescentado no triturado, $450 \mu \mathrm{L}$ de tampão RLT acrescido de 4,5 $\mu \mathrm{L}$ de Beta-mercapetanol, sendo então transferidas para tubos de polipropileno de $1,5 \mathrm{~mL}$. As amostras foram submetidas á agitação vigorosa em Vortex Mixer Genie 2 (Fisher) durante 30 segundos, sendo os lisados transferidos para a coluna lilás (QIAshredder) do kit. As colunas foram centrifugadas a $16100 \mathrm{x}$ g por dois minutos. A coluna foi descartada e a solução resultante foi transferida para um novo tubo de polipropileno de 1,5 mL e adicionado $0,5 \%$ de etanol $95 \%$ gelado, misturado gentilmente pela inversão do tubo. Com auxílio de micropipeta, $650 \mu \mathrm{L}$ da solução foi transferida para a coluna rosa (Mini Spin Column), colocada no tubo de polipropileno de $2 \mathrm{~mL}$ e centrifugada a $8000 \mathrm{x}$ g durante 15 segundos. O filtrado resultante foi descartado e o tubo reutilizado com a coluna rosa, na qual foi adicionado, no mesmo, $700 \mu \mathrm{L}$ de tampão RW1 e centrifugada a 8000 x g por 15 segundos; posteriormente, o filtrado foi descartado e na mesma coluna rosa, foi acrescentado $500 \mu \mathrm{L}$ de tampão RPE e, centrifugado a $8000 \mathrm{x}$ g por 15 segundos. Descartou-se o filtrado e $500 \mu \mathrm{L}$ de tampão RPE foi novamente adicionado a coluna rosa e centrifugado a $8000 \mathrm{x}$ g por dois minutos. Em seguida, à coluna rosa foi transferida para um novo tubo de polipropileno de $1,5 \mathrm{~mL}$ e adicionado $50 \mu \mathrm{L}$ de água (destilada, deionizada, tratada com solução de DEPC e autoclavada) na coluna e centrifugada a $8000 \mathrm{x}$ g por um minuto. Por fim, a coluna foi então descartada e o tubo contendo o filtrado (RNA 
total extraído) foi identificado e mantido no freezer a temperatura de mais ou menos $-26 \pm 1^{\circ} \mathrm{C}$ até posterior uso no teste de RT-PCR.

Teste de Reverse Transcriptase Polymerase Chain Reaction (RT-PCR)

Para o teste de RT-PCR foi seguido o protocolo de Wang et al. (22). A reação foi preparada em um mix em um volume total de $50 \mu \mathrm{L}$ usando os componentes do kit SuperScript ${ }^{\mathrm{TM}}$ III One-Step RT-PCR System with Platinum ${ }^{\mathrm{TM}}$ Taq DNA Polymerase (Thermo Fisher) (Tabela 2) e os primers específicos para os viróides alvos e para a presença de RNA (Controle interno para a verificação da extração de RNA) (Tabela 3). Como controle negativo foi utilizado RNA extraído de Limão 'Cravo' sadio.

Os microtubos foram inseridos no termociclador PTC 200 (MJ Research) seguindo de uma programação de: $50^{\circ} \mathrm{C}$ por 30 minutos; $94^{\circ} \mathrm{C}$ por 2 minutos; 35 ciclos a $94^{\circ} \mathrm{C}$ por 30 segundos, $58^{\circ} \mathrm{C}$ por 30 segundos e $68^{\circ} \mathrm{C}$ por 45 segundos; $68^{\circ} \mathrm{C}$ por 7 minutos e $4^{\circ} \mathrm{C}$ por 5 minutos.

\section{Eletroforese}

Os produtos das reações de RT-PCR foram analisados por eletroforese em gel de agarose a $2 \%$ em tampão TAE $1 \mathrm{X}$ na presença de brometo de etídio $(10 \mathrm{mg} / \mathrm{ml})$, sendo aplicados $16 \mu \mathrm{L}$ do produto do RT-PCR nas canaletas do gel e deixadas por 20 minutos em corrente elétrica a 88 volts. Os amplicons foram visualizados através de transiluminador de luz ultravioleta.

\section{Sequenciamento}

Foram selecionados produtos de RT-PCR de 11 amostras positivas para viróide pertencentes as cinco propriedades analisadas, para fins de sequenciamento no sequenciador ABI 3130XL (Applied Biosystems, Thermo Fisher Scientific), seguindo o protocolo fornecido pelo fabricante.

Os produtos de RT-PCR das amostras escolhidas foram purificados com o Pure Link ${ }^{\circledR}$ PCR Purification kit (Invitrogen EUA), seguindo o protocolo conforme o fabricante, tendo volume final de $30 \mu \mathrm{L}$ do produto da reação de PCR purificado.

Os produtos purificados foram quantificados e submetidos à reação de sequenciamento através do kit Big Dye Terminator Cicle v3.1 (Life Technologies).

Foi utilizado nas reações de sequenciamento o termociclador C100 ${ }^{\mathrm{TM}}$ Thermal Cycler (Bio-Rad Laboratories, Inc.) e realizados individualmente para cada primer.

Para cada reação foi utilizado $1,5 \mu \mathrm{L}$ de tampão (5x), $1 \mu \mathrm{L}$ de Big Dye, $1 \mu \mathrm{L}$ de primer (3,2 pmol), $2 \mu \mathrm{L}$ de DNA purificado e água ultra pura (livre de DNase), completando o volume final para $10 \mu \mathrm{L}$. As condições para a reação de sequenciamento consistiram de: $96^{\circ} \mathrm{C}$ a 1 minuto; 35 ciclos a $96^{\circ} \mathrm{C}$ por 15 segundos, $50^{\circ} \mathrm{C}$ por 15 segundos; $60^{\circ} \mathrm{C}$ por 4 minutos; $4^{\circ} \mathrm{C}$ por 30 minutos. Após a finalização do ciclo as amostras foram precipitadas, a placa no qual estavam os fragmentos a serem sequenciados foi inserida em centrífuga, a 600 rpm, durante um minuto, para que os nucleotídeos livres fossem

Tabela 2. Componentes da reação de RT-PCR e volumes utilizados no preparo do Mix

\begin{tabular}{ccc}
\hline & Componentes da reação de RT-PCR \\
\hline 1 & Agua (destilada deionizada, tratada com DEPC e autoclavada & $17 \mu \mathrm{L}$ \\
$25 \mu \mathrm{L}$ \\
3 & 2 X Mix reaction & $1 \mu \mathrm{L}$ \\
4 & Rever se primer & $1 \mu \mathrm{L}$ \\
5 & Forward primer & $2 \mu \mathrm{L}$ \\
6 & SuperScript ${ }^{\circledR} 111$ RT/Platinum ${ }^{\circledR}$ Taq Mix & $4 \mu \mathrm{L}$ \\
\hline
\end{tabular}

Tabela 3. Primers utilizados na reação de RT-PCR

\begin{tabular}{|c|c|c|c|}
\hline Primer * & Sequência 5'-3' & Tamanho do Amplicon (pb) & Posição \\
\hline CVd-R & CC GGGGAT C CCT GAAGGACTT & 371 & $78-98$ \\
\hline CVd-F & GGAAACCTGGAGGAAGTCGAG & & $99-119$ \\
\hline CBLVd-F & CCCTTCACCCGAGCGCTGCTT & & $188-208$ \\
\hline HSVd-R & CCGGGGCTCCTTTCTCAGGTAAGT & 302 & $59-82$ \\
\hline CVd-III-F & GTCTCCGCTAGTCGGAAAGACTCCG & & $135-159$ \\
\hline CVd-IV-R & CCGGGGATCCCTCTTCAGGT & 138 & $52-71$ \\
\hline CVd-IV-F & GGT GG AT ACAAC TCTT GGGTT GT & & $217-239$ \\
\hline UBQa-R & GTT GATTTTT GCT GGGAAGC & 194 & $571-590$ \\
\hline
\end{tabular}

Adaptado de Wang et al. (2008). *R - Reverse primer, F - Forward primer. CEVd - Citrus exocort viroid; CBLVd - Citrus bent leaf viroid; HSVd - Hop stunt viroid; CVd-III - Citrus dwarfing viroid (CDVd); CVD-IV - Citrus viroid IV; UBQ- Ubiquitina (Controle Interno para a verificação da extração de RNA) 
retirados. Posteriormente, as amostras foram ressuspensas em $30 \mu \mathrm{L}$ de isopropanol a $75 \%$ e a placa incubada por 15 minutos a temperatura ambiente e ao abrigo da luz, cobertas em papel laminado. Após, as mesmas foram centrifugadas a $4.000 \mathrm{rpm}$, a $4^{\circ} \mathrm{C}$ por 45 minutos. Com a finalização dessa etapa, foi retirado o sobrenadante da placa, vertendo a mesma em papel-toalha apoiada em uma bancada. Em seguida a placa foi invertida em papel-toalha e centrifugada a $600 \mathrm{rpm}$, durante 1 minuto, terminado esse processo foi adicionado em cada poço 50 $\mu \mathrm{L}$ de etanol (75\%) e novamente centrifugado a temperatura de $4^{\circ} \mathrm{C}$ a $4000 \mathrm{rpm}$ durante 15 minutos. O sobrenadante foi então descartado, utilizando o papel-toalha como descrito anteriormente, e a placa centrifugada a $600 \mathrm{rpm}$ por um minuto. Terminado esse processo, a placa foi então inserida no termociclador a $60^{\circ} \mathrm{C}$, durante 10 minutos, ao abrigo de luz. A placa foi então mantida a $-20^{\circ} \mathrm{C}$, adequadamente selada e resguardada da luz, até a etapa de sequenciamento.

\section{Análise das Sequências}

As sequências geradas e visualizadas no eletroferograma foram analisadas e, as sequências obtidas com maiores scores de similaridade com as de viróides foram editadas manualmente através do programa Seqman (DNAStar, Madson EUA). No final desse processo, as sequências foram alinhadas de forma que a porção final de uma sequência se sobreponha a porção inicial da outra, formando o contig do genoma completo do viróide. As sequências encontradas de cada amostra foram então comparadas com as sequências de DNA disponíveis no GenBank, através do uso da ferramenta BLASTn (http:// blast.ncbi.nlm.nih.gov).

\section{RESULTADOS E DISCUSSÃO}

Coleta das Amostras e Extração de RNA

Das 22 amostras coletadas no município de Araruama/ RJ foram selecionadas duas plantas de cada propriedade analisada, exceto a propriedade 3, na qual foram avaliadas integralmente as amostras, para a extração de RNA. Todas as amostras analisadas permitiram a extração de RNA de boa qualidade evidenciado pelos amplicons obtidos no teste de RT-PCR.

\section{Inoculação mecânica em Gynura sp.}

Das dez amostras coletadas na propriedade 1 e inoculadas mecanicamente, nenhuma delas ocasionou sintomas em Gynura sp. durante os dias em que foram observadas. Geralmente, essa planta apresenta sintomas da presença do CEVd em pouco tempo, nesse caso não ocorreu nenhum indício de epinastia das folhas, rugosidade, nanismo, característico do $\mathrm{CEVd}$, sendo assim, não foi realizado a extração de RNA das mesmas.

\section{Teste de RT-PCR e eletroforese em gel de agarose}

Nas amostras selecionadas de citros oriundas de cinco propriedades do município de Araruama no Estado do Rio de Janeiro, através de eletroforese em gel de agarose, foram observadas a existência de amplicons entre 269 a 371 pb, atribuídos a viróides.

ITO et al. (12) e SERRA et al. (21) descreveram que plantas cítricas normalmente são hospedeiras de diversas espécies de viróides pertencentes a família Pospiviroidae, fato este verificado em plantações de citros no município de Araruama (RJ) onde foram detectadas quatro espécies de viróides: o CEVd, o CDVd, o HSVd, o CBLVd sendo o CDVd predominante, já que foi detectado nas cinco propriedades, sendo que, a maioria das plantas cítricas apresentavam nanismo (Tabela 4). As amostras das propriedades 01 e 03 apresentaram sintomas bastantes característicos de viróides nas plantas, como rachaduras no tronco, nanismo e epinastia.

Nas análises dos produtos de RT-PCR, com primers específicos para cada um dos viróides, as amostras avaliadas de plantas cítricas enxertadas em Limão 'Cravo' e/ou 'Citrumelo' apresentaram os seguintes resultados: as propriedades $1,2,3$ e 5 foram positivas para o CDVd (269 pb), sendo este agente predominante (Figura 2).

Além do CDVd, as duas amostras pertencentes a propriedade 3 apresentaram banda fraca para CEVd (Figura 3).

Os agentes CDVd (Figura 3), HSVd (Figura 4), CBLVd (Figura 5) foram positivos em uma mesma planta também da propriedade 3 , ou seja, uma mesma planta estava infectada com mais de um viróide, possivelmente, tenha ocorrido uma infecção mista oriundas de mudas já contaminadas ou através de instrumentos de poda contaminados.

Owens et al. (17) demonstraram que onde existia a presença do CDVd ocorreu redução na taxa de crescimento das árvores e, em alguns casos sem induzir sintomas da doença. Sendo assim há uma evidência da influência desse viróide ocasionando nanismo em citros nas propriedades estudadas do Estado do Rio de Janeiro.

Segundo Ito et al. (12) na ausência do CEVd, as plantas de citros infectadas por um conjunto de viróides podem apresentar sintomas semelhantes ao do CEVd confirmando assim, os sintomas causados nas plantas de citros avaliadas, ou seja, rachaduras, nanismo em árvores em que não apresentavam o CEVd.

Ito et al. (12) constataram que no Japão, a infeção mista por CEVd, HSVd e CVd -III (= CDVd) foi a mais encontrada em limões e laranjas, o que também ocorreu, no Estado do Rio de Janeiro.

$\mathrm{Na}$ propriedade 5 as plantas estavam assintomáticas quanto a presença de viróides, no entanto, o Teste de RT-PCR evidenciou a

Tabela 4. Panorama dos viróides encontrados em plantas de citros em de limão da região de Araruama/RJ

\begin{tabular}{|c|c|c|c|c|c|c|c|}
\hline Propriedade & Porta-enxerto & Sintoma* & CDVd & HSVd & CBLVd & CEVd & CVd-IV \\
\hline 2 & 'Citrumelo' & Fraco & + & - & - & - & - \\
\hline 3 & 'Citrumelo'/ Limão 'Cravo' & Forte & + & + & + & + & - \\
\hline 4 & Limão ‘Cravo’ & Médio/ Fraco & + & - & - & - & - \\
\hline
\end{tabular}

*FORTE - presença marcante de rachadura no tronco, nanismo, epinastia; MÉDIO - rachadura no tronco, nanismo; FRACO - rachaduras leves, nanismo pouco acentuado, presença ou não de epinastia nas folhas. NENHUM- sem sintomas aparentes nas plantas 


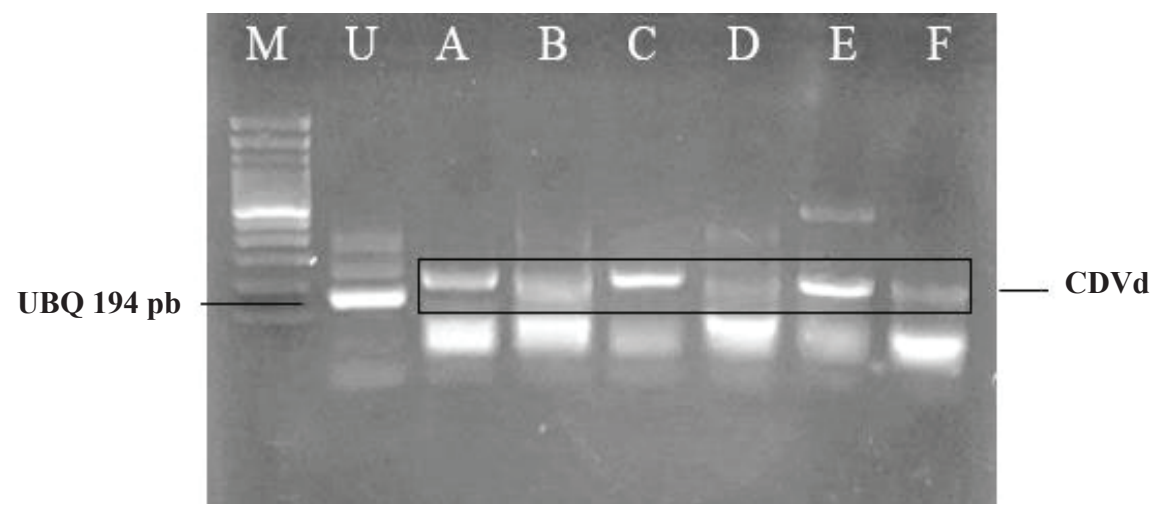

Figura 2. Eletroforese em gel de agarose a 2\% com brometo de etídio - amplificação de RNA por RT-PCR com primers específicos para o CDVd (Amplicon de $269 \mathrm{pb).} \mathrm{Amostra} \mathrm{de} \mathrm{folhas} \mathrm{de} \mathrm{citros} \mathrm{das} \mathrm{propriedades} \mathrm{1,} \mathrm{2,} \mathrm{3,} \mathrm{4,} \mathrm{5.} \mathrm{Amostras:} \mathrm{identificadas} \mathrm{no} \mathrm{gel} \mathrm{pelas} \mathrm{letras} \mathrm{em} \mathrm{sequência} \mathrm{A,} \mathrm{B,} \mathrm{C,}$ D, E e F, sendo a letra F referente também a propriedade 1. M - Marcador de massa molecular (100 pb DNA Ladder, Thermo Fisher); U - Amplicon associada a Ubiquitina (194 pb) utilizado como controle da extração de RNA.

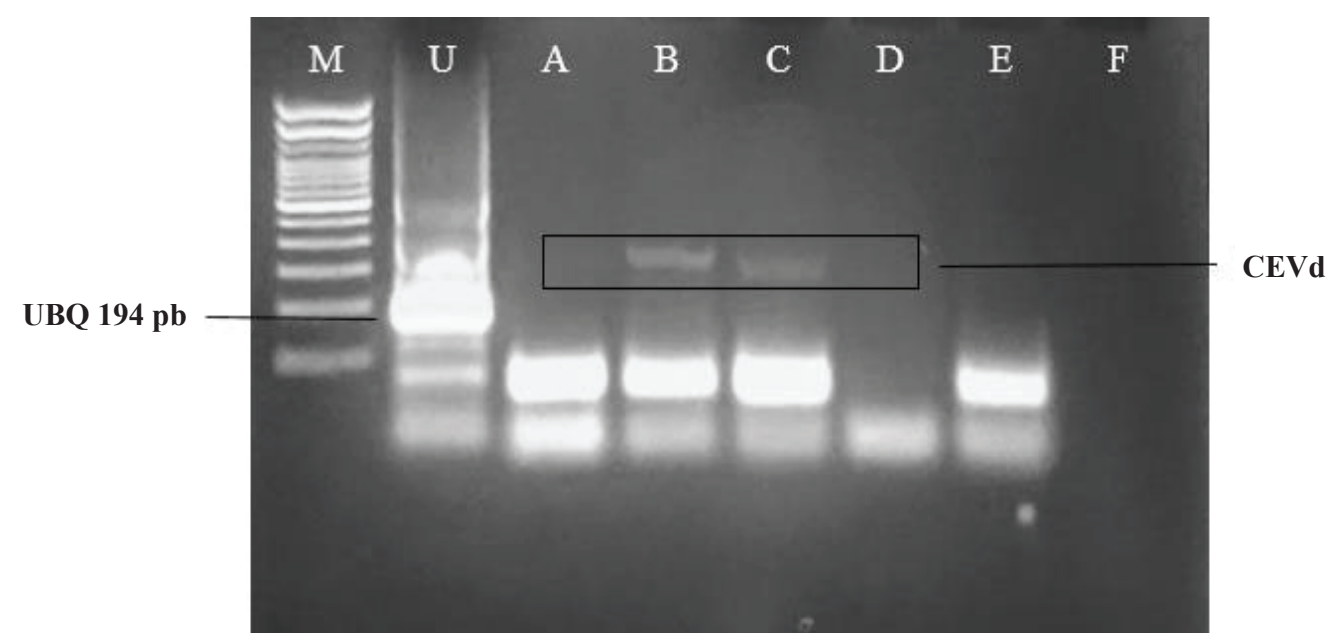

Figura 3. Eletroforese em gel de agarose a 2\% com brometo de etídio - amplificação de RNA por RT-PCR com primers específicos para o CEVd (Amplicon de $371 \mathrm{pb).} \mathrm{Amostras} \mathrm{de} \mathrm{folhas} \mathrm{de} \mathrm{citros} \mathrm{da} \mathrm{propriedade} \mathrm{3.} \mathrm{Amostras:} \mathrm{A} \mathrm{-} 14$ (Planta Sadia); B - 15; C - 16; D - 17; E - Controle negativo da Reação de RT-PCR; F - Controle do ambiente durante a extração do RNA. M - Marcador de massa molecular (100 pb DNA Ladder, Thermo Fisher). U - Amplicon associada a Ubiquitina (194 pb) utilizado como controle da extração de RNA.

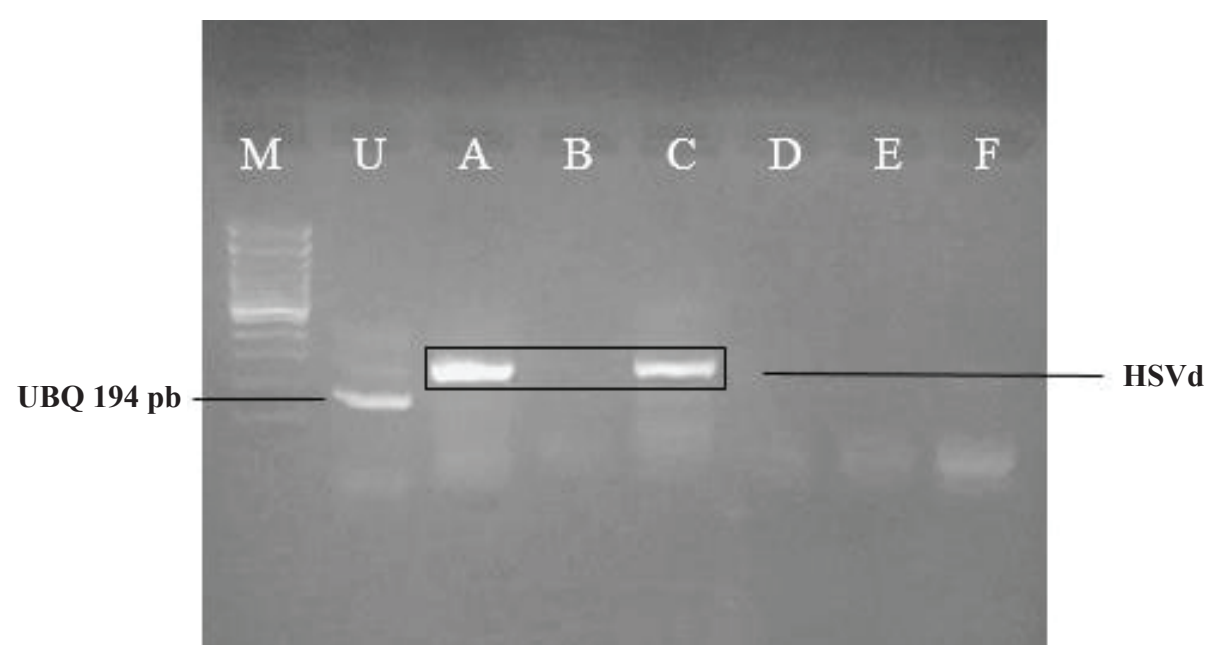

Figura 4. Eletroforese em gel de agarose a 2\% com brometo de etídio - amplificação de RNA por RT-PCR com primers específicos para o HSVd (Amplicon de $302 \mathrm{pb).} \mathrm{Amostra} \mathrm{de} \mathrm{folhas} \mathrm{de} \mathrm{citros} \mathrm{das} \mathrm{propriedades} \mathrm{1,} \mathrm{2,} \mathrm{3,} \mathrm{4,} 5$ identificadas no gel pelas letras em sequência A, B, C, D, E e F, sendo a letra F referente também a propriedade 1. M - Marcador de massa molecular (100 pb DNA Ladder, Thermo Fisher). U - Amplicon associada a Ubiquitina (194 pb) utilizado como controle da extração de RNA. 


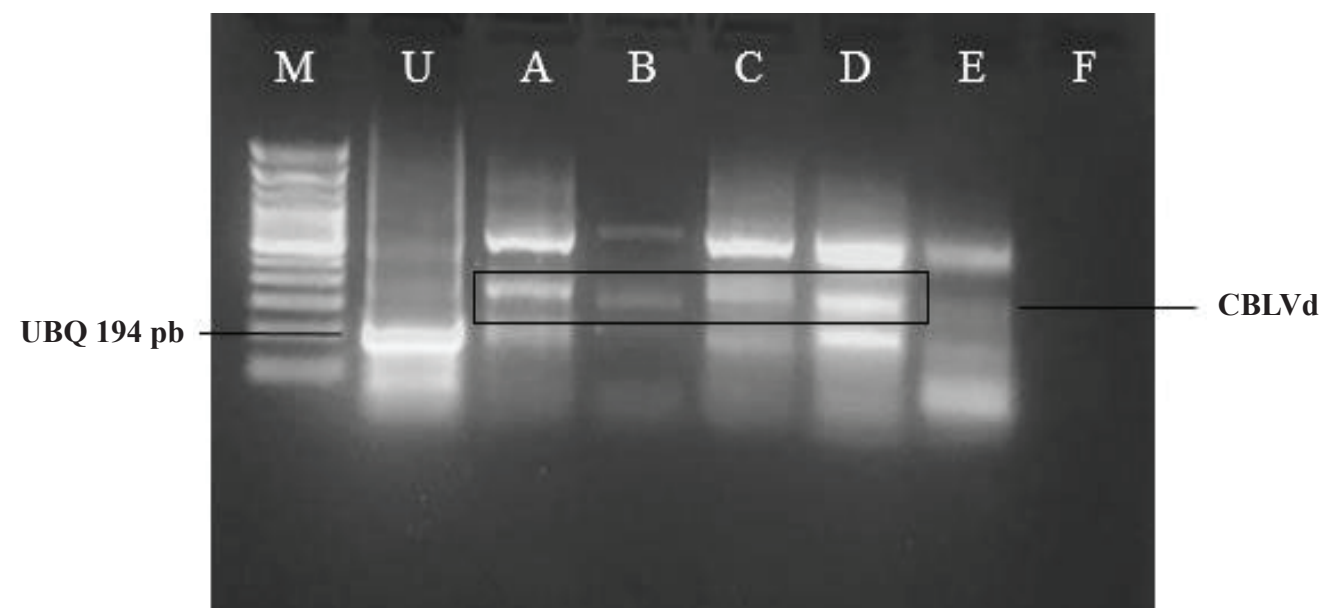

Figura 5. Eletroforese em gel de agarose a 2\% com brometo de etídio - amplificação de RNA por RT-PCR com primers específicos para o CBLVd (Amplicon de 234 pb). Amostras de citros das propriedades 3 e 5. Amostras: A - 14, B - 15, C - 16, D - 21, E - 22, F - Controle do ambiente durante a extração do RNA. M - Marcador de massa molecular (100 pb DNA Ladder, Thermo Fisher). U - Amplicon associada a Ubiquitina (194 pb) utilizado como controle da extração de RNA.

presença de infecção mista com o CDVd e o CBLVd.

Barbosa et al. (1) em seu experimento evidenciaram que a transmissão de viróides pode ocorrer mecanicamente, através de instrumentos de poda, além do CEVd, outros viróides como HSVd, CBLVd, CVd-III (= CDVd) e CVd-IV também podem ser transmitidos por um mesmo instrumento e em condições de campo, sendo esta uma hipótese da presença de diferentes viróides em infecção mista, em todas as propriedades.

Não foi detectado através do teste de RT-PCR a presença do CVd-IV em todas as propriedades analisadas.

Associando os dados de sintomatologia com as do teste de RT-PCR foram identificadas rachaduras acentuadas nos troncos de citros, para a propriedade 1 quando HSVd, CDVd e CBLVd foram combinados. Porém, Ito et al. (12), constataram o aparecimento de leves estrias. Portanto, não se pode afirmar que a combinação desses viróides provoca a presença apenas de rachaduras leves nas plantas.

Wei et al. (23) descreveram a ocorrência do CBLVd em alguns países como Japão, Costa Rica, China entre outros, porém até o momento não havia sido descrita a presença dessa espécie no Brasil.

\section{Análise das Sequências}

Todos os amplicons foram sequenciados sendo as sequências obtidas comparadas com as sequências existentes no banco de dados GenBank.utilizando-se a ferramenta BLASTn

A sequência obtida da amostra da propriedade 1 possui 300 nucleotídeos (Figura 6).apresentando 99\% de identidade com o HSVd isolado PTZ57R/T (Genbank KY654683.1).

Segundo Flores et al. (7), as variantes do viróide HSVd apresentam entre 294 a 303 pb, assim pode-se afirmar que a sequência encontrada é compatível ao HSVd (espécie tipo) pertencente à família Pospiriviroidae do gênero Hostuviroid.

EIRAS (5) descreve em seu trabalho a presença de CEVd e HSVd infectando duplamente videiras no Estado de São Paulo, portanto é necessário cuidado prévio quanto ao plantio de uvas no

$>\mathrm{HSVd}$

GGCAACTCTtCtAGAATCCAGCGAGAGGCGTAGGAGAGAGGGCCGCGGTGC

TCTGGAGTAGAGGCTTCTTGCTTCGAAACACCATCGATCGTCCCTTCTTCTT

TTACCTTCTCCTGGCTCTTCGAGTGAGACGCGACCGGTGGCATCACCTCTC

GGTTCGTCTTCCAACCTGCTTTTTGTCTATCTGAGCCTCTGCCGCGGATCCT

CTCTTGAGCCCCTCTGGGGAATTCTCGAGTTGCCGCaTGGgCAAGCAAAGA

\section{AAAAACAAGGCAGGGAGGAGACTTACCTGAGAAGGAGCCCCGG}

Figura 6. Sequência nucleotídica oriunda do sequenciamento de amostra pertencente a propriedade 1 sendo que o trecho sublinhado corresponde ao Primer Forward e ao Primer Reverse, respectivamente, utilizado no Teste de RT-PCR para a detecção do HSVd. 
Estado do Rio de Janeiro, pois o HSVd é facilmente disseminado por instrumentos de poda e através de mudas infectadas.

No Estado do Rio de Janeiro, a disseminação de viróides pode estar correlacionada ao porta-enxerto Limão 'Cravo' e 'Citrumelo' contaminado, devido á diversificação de viróides encontrados numa mesma planta. $\mathrm{Ou}$, que a incidência desses viróides no Estado do Rio de Janeiro, pode ter ocorrido a partir do transporte de mudas contaminadas oriundas de outros estados, como o Estado de São Paulo.

Até o momento, no Estado do Rio de Janeiro não havia estudos ou trabalhos associados á identificação de viróides em plantas cítricas, trata-se, portanto, do primeiro registro destes viróides em citros no Estado permitindo desta forma a elaboração de uma melhor estratégia de controle que deverá envolver a detecção molecular associado á mudas indexadas e certificadas de plantas cítricas ou de outras hospedeiras (como a videira). Bem como, sugere-se:

- aprimoramento da fiscalização da entrada de mudas no país e implantação de testes moleculares para a identificação de patógenos quarentenários e/ou exóticos evitando assim a disseminação de viróides não existentes no Brasil.

- adoção de Programa de certificação para plantas citricas e outras frutiferas (hospedeiras de viróide) no país devem ser instalados para auxiliar na prevenção e disseminação de viróides.

- controle da disseminação de viróides no Estado do Rio de Janeiro, através da conscientização dos produtores sobre a doença, transmissão e formas de controle.

- levantamentos periódicos associados a testes moleculares devem ser realizados quanto à ocorrência e distribuição geográfica dos viróides (por exemplo, HSVd, CEVd, CDVd e CBLVd) nas áreas de cultivo de citros no Estado do Rio de Janeiro e demais estados produtores do Brasil.

O presente trabalho além de ser inédito no Estado do Rio de Janeiro, contribuiu para a detecção e diagnose pela primeira vez da presença dos viróides CEVd, CBLVd, CDVd e HSVd em plantas cítricas enxertadas em Limão 'Cravo' ou 'Citrumelo' na região.

\section{REFERÊNCIAS}

1. Barbosa, C.J.; Pina, J.A.; Pérez-Panadéz, J.; Bernard, L.; Serra, P.; Navarro, L.; Duran-vila, N. Mechanical transmission of citrus viroids. Plant Disease. Valencia, v.89, n.7, p.749-754, 2005

2. Brioso, P.S.T.; Pozzer, L. Vírus e viróides quarentenários para o Brasil, diagnose e perspectivas futuras. Revisão Anual de Patologia de Plantas. Rio de Janeiro, v.21, p.226-286, 2013.

3. Duran-vila, N.; Roistacher, C.N.; Rivera-Bustamante, R.; Semancik, J.S. A definition of citrus viroid groups and their relationship to the exocortis disease. Journal of General Virology, London, v.69, p.30693080, 1988.

4. Ebrahimi-Moghadam, L.; Zakiaghl, M.; Jafarpour, B.; MEHRVAR, M. Identification of Experimental Herbaceous Host Range of Citrus viroid V. Journal of Agricultural Science and Technology, Mashhad, v.20, p.1279-1291, 2018.

5. Eiras, M. Identificação e caracterização de viróides e estudo de alguns aspectos da interação de viróides com proteínas do hospedeiro. 2006. 109p. Tese (Doutorado em Agronomia/Fitopatologia), Escola Superior de Agricultura Luiz de Queiroz - Universidade de São Paulo. Piracicaba/SP.

6. Eiras, M.; Silva, S.R.; Stuchi, E.S.; Targon, M.L.P.N.; Carvalho, S.A. Viróides e virusóides: relíquias do mundo de RNA. Fitopatologia Brasileira, Brasília, v. 31, n.3, p. 229-246, 2006.

7. Flores, R.; Hernandez, C.; Martínez de Alba, A.E.; Daròs, J.A.; Di serio, F. Viroids and viroid-host interactions. Annual Review of Phytopathology. Palo Alto. v.43, p. 117-139, 2005.

8. Garnsey, S.M.; Randles, J.W. Biological interactions and agricultural implications of. viróides. Viroids and viroid-like pathogens, Boca Raton: CRC Press, p. 177, 1987

9. ICTV. Internacional comittee on Taxoxonomy of Viruses. Taxonomy. Washington, DC, 2018. Disponível em: $<$ https://talk.ictvonline. org/taxonomy/ >. Acesso em: 25 mai. 2018

10. Instituto Brasileiro de geografia e Estatística-IBGE. Indicadores IBGE. Levantamento sistemático da produção agrícola estatística da produção agrícola junho de 2018. Brasília, 2018, p.1-84. Disponível em: < https://www.ibge.gov.br/estatisticas/economicas/agricultura-e-pecuaria/9201-levantamentosistematicodaproducaoagricola.html?edicao $=21697 \& \mathrm{t}=$ downloads? $>$. Acesso em: 05 out. 2018.

11. Instituto Brasileiro de Geografia e Estatística-IBGE. Indicadores IBGE. Levantamento sistemático da produção agrícola estatística da produção agrícola junho de 2017. Brasília, 2017, p. 54-56. Disponível em: < ftp://ftp.ibge.gov.br/Producao_Agricola/Levantamento_Sistematico_ da_Producao_Agricola_[mensal]/Fasciculo_Indicadores_IBGE/2017/ estProdAgr_201706.pdf $>$. Acesso em: 05 out. 2018.

12. Ito, T.; Ieki, H.; Ozaki, K.; Iwanami, T.; Nakahara, K.; Hataya, T.; Ito, T.; Isaka, M.; Kano, T. Multiple citrus viroids in citrus from Japan and their ability to produce exocortis-like symptoms in citron. Phytopathology, St. Paul, v. 92, n.5, p. 542-547, 2002.

13. Jaboticabal. FUNDECITROS. Sumário executivo. Estimativa da safra de laranja 20018/2019 do cinturão citrícola de São Paulo e Triângulo/Sudoeste Mineiro. Jaboticabal, 2018, p.1-4. Disponível em: < http://www. fundecitrus.com.br/pdf/pes_relatorios/2018_09_05_Sum $\% \mathrm{C} 3 \% \mathrm{~A}$ 1rio_Executivo_da_Estimativa_da_Safra_de_Laranja_2018-2019.pdf >. Acesso em 29 ago. 2018.

14. LARANJA. CONAB. Companhia Nacional de Abastecimento. Boletim hortigranjeiro, Brasília/DF, julho/2018, v.4, n.7, p-47-51 2018. Disponível em: < https://www.conab.gov.br/infoagro/hortigranjeirosprohort/ boletim\%20hortigranjeiro >. Acesso em: 05 ago. 2018.

15. Mattos Junior, D.; de Negrini, J.D.; Figueiredo, J.O. de.; Pompeu Junior, J. CITROS: principais informações e recomendações de cultivo. Instituto Agronômico de Campinas. Boletim Técnico IAC. Campinas, n.200, p. 1-9, 2005. Disponível em em: < http://www.iac.sp.gov.br/ imagem_informacoestecnologicas/43.pdf $>$. Acesso em: 28 ago. 2018.

16. Neves, M.F.; Trombin, V.G.; Milan, P.; Lopes, F.F.; Cressoni, R.; kalaki, R. O Retrato da citricultura brasileira. Markestrat. 1. ed. 138 p. Ribeirão Preto, 2010. Disponível em: $<$ http://www.citrusbr.com/ download/Retrato_Citricultura_Brasileira_MarcosFava.pdf $>$. Acesso em: 02 ago. 2018.

17. Owens, R.A.; Yang, G.; Gundersen-Rindal, D.; Hammond, R.W.; Candresse, T.; Bar Joseph, M. Both point mutation and RNA recombination contribute to citrus viroid III senquence diversity. Virus Genes, Beltsvile, v.20, p.243-252, 2000.

18. Pompeu Junior, J. Porta-enxertos. In: Mattos Junior, D.; de Negri, J.D.; Pio, R.M.; Pompeu Junior, J. (Ed.). Citros. Instituto Agronômico e Fundag,Campinas, p. 61-104, 2005.

19. Rio de Janeiro. EMATER Rio de Janeiro. ASPA acompanhamento Sistemático da Produção Agrícola 2018. Secretaria de Agricultura, Pecuária, Pesca e Abastecimento do Estado do Rio de Janeiro, p.1-26, 2018. Disponível em: < http://www.emater.rj.gov.br/areaTecnica/ cult2018.pdf >. Acesso em: 5 fev. 2019.

20. Rio de Janeiro. EMATER Rio de Janeiro. Relatório por municípios do sistema ASPA/AGROGEO-ano 2017. Secretaria de Agricultura, Pecuária, Pesca e Abastecimento do Estado do Rio de Janeiro, Niterói/ RJ, 2017. Disponível em: < http://www.emater.rj.gov.br/images/munic2017.htm >. Acesso em: 28 ago. 2018.

21. Serra, P.; Eiras, M.; Bani Hashemian, S.M, Murcia, N.; Daròs J.A, Flores, R.; Kitajima, E.W.; Duran-Vila, N. Citrus viroid V: occurrence, host range, diagnosis and identification of new variants. Phytopathology, St. Paul, v.98, n.11, 1199-1204, 2008.

22. Wang, X.; Zhou, C.; Tang, K.; Zhou, Y.; Li, Z. A rapid one-step multiplex RT-PCR assay for the simultaneous detection of five citrus viroids in China. European Journal Plant Pathology. Chongqing, v.124, p.175$180,2009$.

23. Wei, Y.; Yasir, K.; Ling, I. L.; Ganesan, K. Citrus bent leaf viroid. Pentanika Journal of Scholarly Research Reviews, Serdang (Selangor, Malaysia), v.3, n.3, p. 31-40, 2017. 